\title{
Hematological, Serum Biochemistry Profile and Nutrient Retention of Finisher Broilers Fed Diet in Which Bio-fermented Rice Husk Meal Substituted Brewer's Dried Grain
}

\author{
J. N. Ikpe ${ }^{1}$, E. C. Oko ${ }^{1} \&$ I. C. Vining-Ogu ${ }^{2}$ \\ ${ }^{1}$ Department of Agricultural Technology, Akanu Ibiam Federal Polytechnic, Unwana Afikpo, Ebonyi, Nigeria \\ ${ }^{2}$ Department of Science Laboratory Technology, Akanu Ibiam Federal Polytechnic, Unwana Afikpo, Ebonyi, \\ Nigeria \\ Correspondence: J. N. Ikpe, Department of Agricultural Technology, School of Industrial Technology, Akanu \\ Ibiam Federal Polytechnic, PMB 1007, Unwana Afikpo, Ebonyi, Nigeria. Tel: 234-080-3492-8358. E-mail: \\ jnikpe@akanuibiampoly.edu.ng
}

Received: October 25, 2018

Accepted: December 18, 2018

Online Published: February 15, 2019

doi:10.5539/jas.v11n3p465

URL: https://doi.org/10.5539/jas.v11n3p465

\begin{abstract}
Heaps of rice husk waste is currently increasing around rice mills in Nigeria. Production cost for broilers has risen tremendously due to high cost of feed ingredients, one of which is Brewer's Dried Grain (BDG). Rice husk has been identified as a potential feed stuff and can replace BDG in broiler production. The research determined the effect of substituting BDG with bio-fermented rice husk meal on the blood profiles and nutrient retention of the broilers. Four treatment diets were formulated. T1 (control) contained 15\% BDG while in T2, T3 and T4 bio-fermented rice husk meal replaced BDG at $33.33 \%, 66.67 \%$ and $100 \%$ to be $5 \%, 10 \%$ and $15 \%$ respectively. The diets were assigned to 120 broilers of 28 days old in a complete randomized design of 10 broilers replicated 3 times. The broilers were reared for 28 days after which blood samples were collected. Nutrient retention of the diets was also analyzed. There was a significant $(\mathrm{P}<0.05)$ reduction in the $\mathrm{WBC}, \mathrm{MCH}, \mathrm{MCHC}$ and serum cholesterol level of broilers on the test ingredient. Nutrient retention showed a significant $(P<0.05)$ increase in ash while the control and T2 were similar $(\mathrm{P}>0.05)$ in crude protein. The research discovered that though there were significant results in most the hematological and biochemical parameters, but the trend of the results was not suggestive that the difference was due to diet. It was concluded that bio-fermented rice husk meal may not have a negative effect on the blood profile of finisher broilers.
\end{abstract}

Keywords: bio-fermented, blood profile, brewer's dried grain, finisher broilers, nutrient retention, rice husk

\section{Introduction}

Rice husk is an agro waste product generated during the milling of rice grain. Rice husk is currently produced in large quantity in Nigeria due to the increasing level of rice production in the country. The annual rice production in Nigeria has increased from 5.5 million tonnes in 2015 to 5.8 million tonnes in 2017 (RIFAN, 2017) and for every $1000 \mathrm{kgs}$ of paddy milled, about $220 \mathrm{kgs}(23 \%)$ of husk is produced (Koteswara, Pranav, \& Anusha, 2012; Benassi et al., 2015). Presently, heaps of rice husks has continued to rise in most milling locations as it is mostly either burnt for heat or dumped as a waste in the majority of rice producing countries (Nwofoke, 2016). Disposing and evacuating the rice dumps is urgently necessary because of the impending environmental hazards, degradation and pollution it poses to the people and the environs (Koteswara, Pranav, \& Anusha, 2012; Haryana, 2018). The exploitation of agro by-products and farm wastes as alternative feed ingredient for poultry and livestock feeding trials has been the current trend in animal production and the potentials of these agro-wastes are yet to be well discovered. Rice husk has long been identified as a feedstuff (Jacquie, 2015) but its problem of high silica, high fibre and abrasive nature make its degradation difficult thereby limiting its utilization as feed ingredient for animals. Different degradation techniques abound which has the tendency of degrading materials thereby reducing its abrasiveness. Methods such as soaking in hot water, irradiation, acid and alkaline hydrolyses, ensiling, fermentation and use of enzymes and antibiotics have been suggested to have the tendency of reducing the limiting factors in rice husk utilization (Longe, 1998; Cobianchi et al., 2012; Jiaying et al., 2016). The current high cost of feeding animals especially the mono gastric animals, due to high cost of conventional feed 
ingredients, has necessitated the need to intensify effort on the discovery of alternative feed ingredients in feeding animals. Such earlier research efforts resulted to the discovery of Brewer's Dried Grain (BDG) in feeding animals. It then became imperative that certain degradation techniques has the tendency to improve the digestibility of rice husk to improve its utilization as a feed ingredient in monogastric animal nutrition. The performance indications of an animal as a result of consumption of a feed ingredient is not the only indicator for its efficiency, as some feed ingredient though good in performance indication but can impact negatively on other valuable parameters of the animal. Elagib and Ahmed (2011) reported that valuable information can be obtained from the study of the hematological parameters as blood serves as an important index of physiological, pathological and nutritional status of an animal and Information obtained from the assay, is useful for diagnostic and management purposes. Hematological components are valuable in monitoring feed toxicity as well as the health status of farm animals (Oyawoye \& Ogunkunle, 2004; Etim et al., 2013). Hematology and serum biochemistry assay of livestock suggests the physiological disposition of the animals to their nutrition and it has been found that various feed stuffs including unconventional sources may have effect on the hematology and serum biochemistry of livestock and hence concluded that feed ingredients may affect animals (Madubuike \& Ekenyem, 2006; Zhang et al., 2013; Hrabčáková et al., 2014; Alabi et al., 2015).

This study was therefore designed to determine the effect substituting BDG with bio-fermented rice husk meal in finisher broiler's diet, on the hematology, serum biochemistry and nutrient retention of the finisher broilers.

\section{Materials and Methods}

\subsection{Study Area}

The research was conducted at the Teaching and Research Farm, Department of Agricultural Technology, Akanu Ibiam Federal Polytechnic Unwana, Afikpo, Ebonyi State. Unwana is in the tropical rain forest zone of Nigeria.

\subsection{Collection of the Rice Husk}

The rice husk used for the research was obtained from one of the numerous rice mills at Eke market in Afikpo, Ebonyi State, Nigeria. The rice husk was transported to the Teaching and Research Farm of Akanu Ibiam Federal Polytechnic, Unwana, Nigeria.

\subsection{Nature and Sieve Analysis of the Rice Husk Used for the Research}

The rice husk used for the research comprises of variable sizes of particles of rice husk.

The sieve analysis of $100 \mathrm{gm}$ of the rice husk done using a British standard meshes of $500 \mu, 425 \mu, 250 \mu, 180$ $\mu$, pan and a sensitive digital scale is as follows:

$500 \mu=69.2 \%$; $425 \mu=9.02 \% ; 250 \mu=8.11 \% ; 180 \mu 6.48 \%$; Less than $180 \mu 7.17 \%$.

\subsection{Degradation of the Rice Husk}

Biofermentation of rice husk was carried out according to the procedure described by Fasuyi and Olumuyiwa (2012). A mixture of rice husk, water and Blackstrap molasses syrup was made in the ratio of $60 \mathrm{Kg}$ to 60 liters to 3 liters respectively and was compressed into 150 liters capacity plastic container. The mixture was compressed manually as it was poured in, till the container was about $3 / 4$ filled. To ensure anerobic condition, the container was carefully covered with thick nylon covering. Sand was poured on top to the rest of the space and another nylon spread across to cross the rilm of the container before covering with its lid. The fermentation took place for twenty one days after which the container was opened. The layer of sand was gently removed and the husk was poured out into a clean slab and sun dried till to about $12 \%$ moisture content. Proximate composition of the biofermented rice husk and untreated rice husk was analyzed as described by AOAC (2000). The dried bio-fermented rice husk was used for the formulation of the treatment diets.

\subsection{Experimental Birds and Design}

A total of 120 Marshal breed of broilers of 28 days of age and of an average weight of 738 gms, were used for the experiment. The broilers were randomly assigned to four treatment goups in a Completely Randomized Design (CRD). Each treatment group was replicated 3 times to obtain a total of 12 groups of 10 broiler each. Treatment 1 was the control group. Treatments 2,3 and 4 contained bio-fermented rice husk at $5 \%, 10 \%$ and $15 \%$ inclusion rates respectively. The broilers were randomly assigned to an experimental units partitioned $1 \mathrm{~m}$ by $1 \mathrm{~m}$ each and raised under a deep liter system of management. Feed and water were given ad-libitum and proper routine management practices and medications were adopted strictly in accordance with approved established standard guiding the institution. The feeding trial lasted for 28 days. 


\subsection{Data Collection}

At the end of the 28 days feeding period, 3 broilers were randomly selected from each of the replicates to give 9 broilers per treatment and a total of 36 broilers, for blood collection.

\subsubsection{Hematological Indices}

The blood for the blood profile assessment was collected in accordance with approved established standard guiding the institution. The blood was collected from each of the selected broilers by puncturing the webal sub-clavicles vein with five milliliters scalp vein needle set. Two milliliters of blood was collected into a bottle containing ethylene diamine tetra-acetic acid (EDTA) as an anti-coagulant and the following parameters analyzed using Sysmex Auto Analyzer: Hemoglobin Concentration ( $\mathrm{Hb}$ ), Packed Cell Volume (PCV), Total White Blood Cells (WBC[t]), the Red Blood Cells (RBC), Mean Cell Volume (MCV), Mean Cell Hemoglobin $(\mathrm{MCH})$ and Mean Cell Hemoglobin Concentration (MCHC). The procedure for the analyses were as follows: The blood containing the EDTA was homogenized by gentle agitation of the container. The sample was placed in the aspiration nozzle of the auto analyzer and the "START" button switched on. The sample was removed after aspiration. The machine automatically analyzed the sample and display "Print out the result". The white Blood Cells differential (WBC-Differential) Heterophil, Eosinophils, Basophils, Lymphocytes and monocytes were counted by preparing a thin film blood smear slides of each of the sample, the slide was allowed to dry and then stain with LEISHMAN'S stain. Immersion oil was applied and the different White Blood Cell counted under a microscope adopting longitudinal method of counting.

\subsubsection{Serum Biochemical Indices}

Blood for biochemistry analysis was obtained by collecting another three $\mathrm{ml}$ blood into a test tube, with no anti-coagulant. The coagulated blood was subjected to standard method of serum separation and the harvested sera analyzed using RANDOX kit specified for each the parameters and a spectrophotometer. The parameters analyzed include: the kidney function - urea and creatinine, the cholesterol, total proteins and albumin, the glucose; the electrolytes - sodium, potassium, chlorine, and the liver enzymes-Alkaline phosphatase (ALP), Aspartate aminotransferase (AST) and Alanine aminotransferase (ALT). The liver enzymes were analyzed adopting the method of Reitman and Frankel (1957), the serum proteins was analyzed adopting the method of Flack and Woollen (1984), and the serum creatinine was analyzed adopting the method of Henry (1974), the serum sodium was analyzed using the method described by Trinder (1951) method of Allain et al. (1974), and Steele et al. (1976) was adopted in analyzing the serum cholesterol while glucose was analyzed with single touch Accu-check glucometer produced by Roche diagnostics, Germany.

\subsubsection{Nutrient Retention}

Three broilers each were randomly selected from each of the replicates and transferred to their different metabolic cages for the nutrient retention analysis. The broilers were allowed 3 days to stabilize in the metabolic cage before the commencement of data collection. The broilers were given $90 \%$ of their daily feed intake every 24 hours. The fecal waste from each of the treatment groups were collected, dried and weighed for 7 days. The fecal waste together with the samples of the treatment diets were analyzed of their proximate composition according to AOAC (2000). The results obtained from both the treatment diets and the fecal wastes were used in determining the nutrient retention level of the diets by the broilers.

$$
\text { Nutrient retention }=\frac{\text { Nutrient in feed }- \text { Nutrient in feces }}{\text { Nutrient in feed }} \times 100
$$

\subsection{Experimental Diets}

A total of 4 experimental diets were formulated for the research. $T_{1}$ which was the control contained no rice husk. $\mathrm{T}_{2}, \mathrm{~T}_{3}$ and $\mathrm{T}_{4}$ contained bio-fermented rice husk. The rice husk replaced Brewer's Dried Grain at 33.33\%, $66.67 \%$ and $100 \%$ for $\mathrm{T}_{2}, \mathrm{~T}_{3}$ and $\mathrm{T}_{4}$ in each of these diets on weight to weight basis. The ingredient composition of the experimental diets is presented in Table 1 . 
Table 1. Ingredient composition of the experimental diets

\begin{tabular}{lllll}
\hline \multirow{2}{*}{ Ingredients } & \multicolumn{3}{c}{ Dietary levels $(\%)$} \\
\cline { 2 - 4 } & $\mathrm{T} 1(0.00)$ & $\mathrm{T} 2(5.00)$ & $\mathrm{T} 3(10.00)$ & $\mathrm{T} 4(15.00)$ \\
\hline Maize 9\%CP & 55.00 & 55.00 & 55.00 & 55.00 \\
Soya Bean Meal 44\%CP & 5.00 & 5.00 & 5.00 & 5.00 \\
Groundnut Cake 45\%CP & 13.00 & 13.00 & 13.00 & 13.00 \\
Bio-fermented rice husk Meal 4.22\%Cp & 0.00 & 5.00 & 10.00 & 15.00 \\
Brewer's Dried Grain 27\%CP & 15.00 & 10.00 & 5.00 & 0.00 \\
Fish Meal 63\%CP & 3.00 & 3.00 & 3.00 & 3.00 \\
Blood Meal 77\%CP & 3.00 & 3.00 & 3.00 & 3.00 \\
Bone Meal nil & 5.00 & 5.00 & 5.00 & 5.00 \\
**Premix & 0.25 & 0.25 & 0.25 & 0.25 \\
Lysine & 0.25 & 0.25 & 0.25 & 0.25 \\
Methionine & 0.25 & 0.25 & 0.25 & 0.25 \\
Common salt & 0.25 & 0.25 & 0.25 & 0.25 \\
Total & 100 & 100 & 100 & 100 \\
\hline Analysed nutrient composition of the experimental diets & 21.23 & 20.12 & 19.62 & 19.24 \\
Crude protein, (\%) & 7.35 & 9.74 & 9.85 & 12.98 \\
Crude fiber, (\%) & 3.96 & 3.92 & 4.19 & 4.06 \\
Crude fat, (\%) & 2945.33 & 2918.66 & 2842.41 & 2812.46 \\
*Metabilizable energy (kcal/kg) &
\end{tabular}

Note. ** To provide the following per kilogram of feed; vit A 10,000IU; vit. D3 1,500 IU; vit. E $2 \mathrm{mg}$; riboflavin $3 \mathrm{mg}$; pantothenic acid $10 \mathrm{mg}$; nicotinic acid, $2.5 \mathrm{mg}$; choline $3.5 \mathrm{mg}$; folic acid $1 \mathrm{mg}$; magnesium $56 \mathrm{mg}$; lysine $1 \mathrm{mg}$; iron $20 \mathrm{mg}$; zinc $50 \mathrm{mg}$; cobalt $1.25 \mathrm{mg}$. *The metabolizable energy of the test ingredient was calculated using prediction equation as reported by Pauzenga, 1985 with the formula M.E $=37 \times \% \mathrm{CP}+81.8 \times \% \mathrm{EE}+$ $35.5 \times \% \mathrm{NFE}$.

\subsection{Data Analysis}

The data obtained from this study, were subjected to statistical analysis using analysis of variance procedure and computed with IBM SPSS version 22. Significantly difference $(\mathrm{P}<0.05)$ means were compared using Duncan Multiple Range Test (Duncan, 1955).

\section{Results}

\subsection{Proximate Composition}

The result of the proximate analysis of the bio-fermented rice husk meal used for the study is presented in Table 2. The result showed that the treated rice husk meal contains $4.22 \%$ crude protein, $37.34 \%$ crude fiber, $2.90 \%$ ether extract., $17.68 \%$ ash and calculated nitrogen free extract of $27.86 \%$. While the untreated rice husk contained $5.24 \%$ crude protein, $59.20 \%$ crude fiber, $3.40 \%$ ether extract, $16.35 \%$ ash and a calculated nitrogen free extractof $4.84 \%$.

Table 2. Proximate composition of the bio - fermented and untreated rice husk meal

\begin{tabular}{lll}
\hline \multirow{2}{*}{ Nutrient } & \multicolumn{2}{c}{ Proximate Composition (\%DM) } \\
\cline { 2 - 3 } & Bio-fermented rice husk & Untreated rice husk \\
\hline Dry matter content & 90.00 & 89.03 \\
Crude Protein & 4.22 & 5.24 \\
Crude fiber & 37.34 & 59.20 \\
Ether extract & 2.90 & 3.40 \\
Ash content & 17.68 & 16.35 \\
Nitrogen Free Extract & 27.86 & 4.84 \\
\hline
\end{tabular}

Note. $\mathrm{DM}=$ Dry matter. 


\subsection{Hematological Indices}

The result of the hematological analysis of the broilers fed diet containing bio-fermented rice husk is presented in Table 3. The result showed that the broilers in the control group had a significantly $(\mathrm{P}<0.05)$ highest values in WBC, monocytes, $\mathrm{MCH}$ and $\mathrm{MCHC}$ The value of lymphocytes was least in the control group which was $27.00 \%$, followed by T3 which was $30.00 \%$ and similar with $\mathrm{T} 4$ which was $32.00 \%$ while $\mathrm{T} 2$ had the highest value of $33.00 \%$ which was similar $(\mathrm{P}>0.05)$ with $\mathrm{T} 4$. The $\mathrm{PCV}$ value of broilers in the control group was similar $(\mathrm{P}>$ $0.05)$ with $\mathrm{T} 2$ which were $52.70 \%$ and $52.30 \%$ respectively but significantly $(\mathrm{P}<0.05)$ higher than value obtained in T3 and T4 which also were similar $(\mathrm{P}>0.05)$ being $50.80 \%$ and $50.30 \%$ respectively. The values obtained in RBC and MCV did not follow a definite trend to attribute the differences to diets while the values obtained in $\mathrm{Hb}$ and Basophil did not differ $(\mathrm{P}>0.05)$ among the treatment groups.

Table 3. Hematological indices of finisher broilers fed different levels of bio-fermented rice husk meal

\begin{tabular}{llllll}
\hline \multirow{2}{*}{ Parameters } & \multicolumn{5}{c}{ Dietary levels $(\%)$} \\
\cline { 2 - 5 } & $\mathrm{T}_{1}(0.00)$ & $\mathrm{T}_{2}(5.00)$ & $\mathrm{T}_{3}(10.00)$ & $\mathrm{T}_{4}(15.00)$ & SEM \\
\hline RBC $\left(\times 10^{12} / \mathrm{L}\right)$ & $3.14^{\mathrm{b}}$ & $3.6^{\mathrm{a}}$ & $3.00^{\mathrm{b}}$ & $3.12^{\mathrm{b}}$ & 0.12 \\
$\mathrm{PCV}(\%)$ & $52.70^{\mathrm{a}}$ & $52.30^{\mathrm{a}}$ & $50.80^{\mathrm{b}}$ & $50.30^{\mathrm{b}}$ & 0.33 \\
$\mathrm{Hb}(\mathrm{g} / \mathrm{dl})$ & 12.00 & 11.50 & 11.00 & 11.20 & 0.45 \\
WBC $\left(\times 10^{9} / \mathrm{L}\right)$ & $203.70^{\mathrm{a}}$ & $186.00^{\mathrm{d}}$ & $200.00^{\mathrm{b}}$ & $193.20^{\mathrm{c}}$ & 1.46 \\
WBC differentials $(\%)$ & & & & \\
Hetrophils & $63.00^{\mathrm{a}}$ & $59.00^{\mathrm{c}}$ & $63.00^{\mathrm{a}}$ & $61.00^{\mathrm{b}}$ & 0.82 \\
Eosinophil & $3.00^{\mathrm{a}}$ & $3.00^{\mathrm{a}}$ & $2.00^{\mathrm{b}}$ & $2.00^{\mathrm{b}}$ & 0.17 \\
Basophils & 1.00 & 1.00 & 1.00 & 1.00 & 0.04 \\
Lymphocytes & $27.00^{\mathrm{c}}$ & $33.00^{\mathrm{a}}$ & $30.00^{\mathrm{b}}$ & $32.00^{\mathrm{ab}}$ & 1.08 \\
Monocytes & $6.00^{\mathrm{a}}$ & $4.00^{\mathrm{b}}$ & $4.00^{\mathrm{b}}$ & $4.00^{\mathrm{b}}$ & 0.48 \\
MCV (fl) & $167.83^{\mathrm{b}}$ & $145.28^{\mathrm{d}}$ & $169.33^{\mathrm{a}}$ & $161.22^{\mathrm{c}}$ & 0.12 \\
MCH (Pg) & $38.22^{\mathrm{a}}$ & $31.94^{\mathrm{d}}$ & $36.67^{\mathrm{b}}$ & $35.93^{\mathrm{c}}$ & 0.14 \\
MCHC (g/dl) & $227.03^{\mathrm{a}}$ & $219.53^{\mathrm{c}}$ & $216.53^{\mathrm{d}}$ & $222.66^{\mathrm{b}}$ & 0.09 \\
\hline
\end{tabular}

Note. Without superscript $=$ not significant. Means with different superscript in the same row differ significantly ( $\mathrm{P}$ $<0.05$ ).

$\mathrm{SEM}=$ Standard Error Mean. $\mathrm{RBC}=$ Red Blood Cell. $\mathrm{PCV}=$ Packed Cell Volume, $\mathrm{Hb}=$ Hemoglobin concentration, $\mathrm{WBC}=$ White Blood Cell, $\mathrm{MCV}=$ Mean Cell Volume, $\mathrm{MCH}=$ Mean Cell Hemoglobin, $\mathrm{MCHC}=$ Mean Cell Hemoglobin Concentration.

\subsection{Serum Biochemical Indices}

The result of the biochemical indices of the broilers fed diets containing different levels of bio-fermented rice husk meal is presented in Table 4. The result showed a significant $(\mathrm{P}<0.05)$ result for all the parameters analyzed. The values however did not present a definite trend suggestive of dietary effect except in cholesterol and creatinine which had a reduced value for broilers on the test ingredient while Na, CL, AST and ALT had an increased value for broilers on the test ingredient. The value obtained for cholesterol from broilers in the control group was $78.74 \mathrm{mg} / \mathrm{dl}$ which reduced significantly $(\mathrm{P}<0.05)$ to $54.83 \mathrm{mg} / \mathrm{dl}, 57.49 \mathrm{mg} / \mathrm{dl}$ and $51.59 \mathrm{mg} / \mathrm{dl}$ for broilers on $\mathrm{T} 2, \mathrm{~T} 3$ and $\mathrm{T} 4$ respectively. 
Table 4. Biochemical indices of finisher broilers fed different levels of bio-fermented rice husk meal

\begin{tabular}{|c|c|c|c|c|c|}
\hline \multirow{2}{*}{ Parameters } & \multicolumn{5}{|c|}{ Dietary levels (\%) } \\
\hline & $\mathrm{T} 1(0.00)$ & $\mathrm{T} 2(5.00)$ & $\mathrm{T} 3(10.00)$ & $\mathrm{T} 4(15.00)$ & SEM \\
\hline Urea (mmol/L) & $10.21^{\mathrm{c}}$ & $9.87^{\mathrm{d}}$ & $12.10^{\mathrm{a}}$ & $11.65^{b}$ & 0.10 \\
\hline Creatinine $(\mathrm{mmol} / \mathrm{L})$ & $0.66^{\mathrm{a}}$ & $0.57^{\mathrm{c}}$ & $0.60^{\mathrm{b}}$ & $0.62^{\mathrm{b}}$ & 0.01 \\
\hline cholesterol(mg/dl) & $78.74^{\mathrm{a}}$ & $54.83^{\mathrm{c}}$ & $57.49^{\mathrm{b}}$ & $51.59^{\mathrm{d}}$ & 0.11 \\
\hline Total Protein $(\mathrm{g} / \mathrm{dl})$ & $3.78^{\mathrm{c}}$ & $4.16^{\mathrm{b}}$ & $4.64^{\mathrm{a}}$ & $3.74^{\mathrm{c}}$ & 0.07 \\
\hline Albumin $(\mathrm{g} / \mathrm{dl})$ & $2.05^{\mathrm{c}}$ & $2.29^{\mathrm{b}}$ & $2.81^{\mathrm{a}}$ & $1.93^{\mathrm{d}}$ & 0.03 \\
\hline $\mathrm{Na}^{+}(\mathrm{mEq} / \mathrm{l})$ & $128.37^{\mathrm{d}}$ & $135.21^{\mathrm{c}}$ & $137.74^{\mathrm{a}}$ & $136.91^{\mathrm{b}}$ & 0.09 \\
\hline $\mathrm{K}^{+}(\mathrm{mEq} / \mathrm{l})$ & $4.10^{c}$ & $4.97^{b}$ & $6.19^{\mathrm{a}}$ & $3.85^{\mathrm{d}}$ & 0.05 \\
\hline $\mathrm{Cl}^{-}(\mathrm{mEq} / \mathrm{l})$ & $96.76^{\mathrm{d}}$ & $103.28^{\mathrm{c}}$ & $108.51^{\mathrm{a}}$ & $104.25^{\mathrm{b}}$ & 0.18 \\
\hline Alkaline phosphatase (ALP) $(\mathrm{u} / \mathrm{l})$ & $53.70^{\mathrm{b}}$ & $55.50^{\mathrm{a}}$ & $53.21^{\mathrm{b}}$ & $53.66^{\mathrm{b}}$ & 0.36 \\
\hline Aspartate aminotransferase (AST) $(\mathrm{u} / \mathrm{l})$ & $20.00^{\mathrm{b}}$ & $24.00^{\mathrm{a}}$ & $25.00^{\mathrm{a}}$ & $25.00^{\mathrm{a}}$ & 0.74 \\
\hline Alanine aminotransferase (ALT) $(\mathrm{u} / \mathrm{l})$ & $15.00^{\mathrm{c}}$ & $18.00^{\mathrm{b}}$ & $20.00^{\mathrm{a}}$ & $20.00^{\mathrm{a}}$ & 0.74 \\
\hline
\end{tabular}

Note. Without superscript $=$ not significant. Means with different superscript in the same row differ significantly $(\mathrm{P}$ $<0.05)$. SEM $=$ Standard Error Mean.

\subsection{Nutrient Retention}

The result of nutrient retention of the broilers fed diets containing different levels of bio-fermented rice husk meal is presented in Table 5. The result showed that the broilers in the control group retained least ash which was $21.75 \%$, followed by T2 which was $29 \%$ while T3 and T4 were similar $(\mathrm{P}>0.05)$ and retained the highest which were $52.00 \%$ and $51.76 \%$ respectively. The value of crude protein retention was similar $(\mathrm{P}>0.05)$ for the control group and $\mathrm{T} 2$ which were $85.48 \%$ and $85.74 \%$ respectively but significantly $(\mathrm{P}<0.05)$ higher than $\mathrm{T} 4$ which was $84.16 \%$ while $\mathrm{T} 3$ had the least value which was $79.30 \%$. The crude fiber and the ether extract was also significant $(\mathrm{P}<0.05)$ among the treatment groups.

Table 5. Nutrient Retention of Finisher Broilers Fed different Levels of bio-fermented rice husk meal

\begin{tabular}{llllll}
\hline \multirow{2}{*}{ Parameters (\%) } & \multicolumn{5}{c}{ Dietary levels (\%) } \\
\cline { 2 - 5 } & T1(0.00) & T2(5.00) & T3(10.00) & T4(15.00) & SEM \\
\hline Ash & $21.75^{\mathrm{c}}$ & $29.00^{\mathrm{b}}$ & $52.00^{\mathrm{a}}$ & $51.76^{\mathrm{a}}$ & 0.59 \\
Crude fiber & $23.58^{\mathrm{c}}$ & $15.53^{\mathrm{d}}$ & $29.84^{\mathrm{b}}$ & $54.48^{\mathrm{a}}$ & 0.04 \\
Crude protein & $85.48^{\mathrm{a}}$ & $85.74^{\mathrm{a}}$ & $79.30^{\mathrm{c}}$ & $84.16^{\mathrm{b}}$ & 0.14 \\
Ether extract & $92.34^{\mathrm{b}}$ & $92.71^{\mathrm{b}}$ & $93.44^{\mathrm{a}}$ & $91.71^{\mathrm{c}}$ & 0.20 \\
\hline
\end{tabular}

Note. Without superscript $=$ not significant. Means with different superscript in the same row differ significantly $(\mathrm{P}$ $<0.05)$. SEM $=$ Standard Error Mean.

\section{Discussion}

\subsection{Proximate Composition}

The result when compared with the result obtained from non-treated rice husk showed that bio fermentation decreased the crude protein and ash content of the rice husk while the crude fibre and ether extract cotent reduced. The finding conform with the report of Fasunyi and Olumiyiwa (2012).

\subsection{Hematological Profile}

In the present research, the WBC of the broilers in the control group had a higher value than the broilers on the test ingredient. The primary role of the WBC is defense; it rises in event of issues it must fight (Graham, 2010). The WBC of broilers fed the test ingredient reduced which may be attributed to reduction in the microbial load of the broilers. However, in the present research, the lymphocytes fraction of the white blood cell differential which constitute the majority of the leukocytes (WBC) in the blood of the fowl and whose main function is to produce antibodies and to attack infected or abnormal cells (Lane, 2002) had a higher value for broilers on the test ingredient. This could compensate for the low value obtained in the WBC of broilers on the test ingredient treatment groups. The RBC, which is the total red blood count (Jaime, 2005) of the broilers in the present experiment did not present a definite trend to attribute the difference to dietary effect hence the MCH which is expression of the average hemoglobin content of a single $\mathrm{RBC}$ and the $\mathrm{MCHC}$ which is the expression of the 
volume within the RBC occupied by the hemoglobin (Jaime, 2005) though significantly higher for broilers in the control group but their values for the broilers on the test ingredient did not also present a definitive trend suggestive of dietary difference effect. The $\mathrm{Hb}$ which is the oxygen carrying protein matrix in the RBC (Graham, 2010) was similar among all the groups which is an indication that both the BDG and the bio-fermented rice husk may have impacted on the $\mathrm{Hb}$ in the same way.

\subsection{Serum Biochemical Profile}

The reduction in the value of cholesterol for broilers fed the test ingredient as obtained in the present research may be an indication that the test ingredient had an effect on the serum cholesterol of the broilers. A decrease in serum cholesterol has been ascribed to indicate an impaired lipid metabolism and transportation (Champe, Harvery, \& Ferrier, 2008). The cholesterol concentration will vary with bird's diet and a decrease in cholesterol level has been associated with some cases of reduced fat in the diet (Manfred, 2013). In the present study, the calculated crude fat content of the diets was highest in control diet which may have accounted for the highest cholesterol value obtained from the serum of broilers in this group. The reduction in the serum cholesterol among the treatment groups in the present study however did not reduce accordingly with increase in inclusion levels of the test ingredients as the cholesterol level of T3 which was $57.49 \mathrm{mg} / \mathrm{dl}$ was higher than $54.83 \mathrm{mg} / \mathrm{dl}$ which was the value for $\mathrm{T} 2$. The $\mathrm{T}_{4}$ diet which had the least crude fat composition however, had the least serum cholesterol level. The reduced fat content of the diets containing the test ingredient could have caused a reduction in the triglyceride biosynthesis and favored the re-distribution of cholesterol among the lipoprotein molecules to result in the reduction in the serum cholesterol. The reduction in cholesterol level as obtained in the present study however is an advantage especially now that people are very conscious of reducing cholesterol content of their animal protein source. The liver enzymes (the AST and the ALT) in the present study increased with the inclusion of the test ingredient. Both the AST and the ALT have been described as not being specific for determining hepatocellular damage in poultry, but are highly sensitive in detecting hepatocellular damage caused by ethylene glycol in pigeons (Lumeij, 1998). Hence, the elevation in the AST and the ALT may not be attributed to indication of hepatocellular damage. The serum electrolytes (sodium, potassium and the chlorides) in the present study increased significantly for the groups on the test ingredient. Sodium, potassium and chlorides play a crucial role in maintaining body acid-base balance as well as osmotic pressure in body fluids and the role of each individual component is difficult to define without knowing and taking into consideration the other two elements (Milica et al., 2016). However, the significant result obtained in these parameters in the present study is an indication that the test ingredient may not be comparable with $\mathrm{BDG}$ for these serum biochemical parameters.

\subsection{Nutrient Retention}

The high level of ash retained by broilers on the fermented rice husk meal as obtained in the present research could be as a result of the higher ash content of rice husk when compared with that contained in BDG. Rice husk has been described as having a higher content of ash as compared to other agricultural residues (Ubwah et al., 2014). This may have affirmed to the high ash content of the broilers fed rice husk meal especially at high inclusion levels irrespective of the bio fermentation treatment of the rice husk. The bio fermentation reduced the crude fiber retention in T2, but increased it at higher inclusion rate of T4. The high fiber retention for the broilers at high inclusion rate could be due to high fiber content of the rice husk as reported by (Jacquie, 2015). The crude protein retention in the present research dropped at T3 and T4 levels while T2 value was similar $(\mathrm{P}>0.05)$ with the control. Alabi, Atteh and Ogunniyi (2014) also reported a reduction in protein retention at increase dietary level of rice husk in the absence of enzyme supplementation. The bio fermentation treatment could have ameliorated the nutrient content of the rice husk which led to the similarity in the value of crude protein retention between broilers in the control group and the broilers at lower inclusion rate of 5\% (T2) which also had a reduced crude fiber value.

\section{Conclusion}

The present research revealed that bio-fermented rice husk could effectively replace BDG in finisher broiler diet without impacting negatively on the hematological and biochemical profile. Though there was significant results in most of the hematological and biochemical parameters analyzed, but the sequence of the significant results was not suggestive that the differences were due to diet while the parameters that presented sequential definite trend were not parameters to cause damage to broilers. Bio-fermented rice husk in the diet of broilers caused a marked reduction in the serum cholesterol and a marked ash retention.

\section{Acknowledgement}

The researchers immensely wish to thank the management of Akanu Ibiam Federal Polytechnic Unwana for giving us the opportunity to participate in the Institution Based Research. We also thank the Tertiary Education 
Trust Fund (TETfund) of the Federal Government of Nigeria for providing us with a research grant to explore the Potentials of Rice Husk - a hitherto increasingly-generated agricultural waste.

\section{References}

AOAC (Association of Official Analytical Chemists). (2000). Official methods of analysis (17th ed.). AOAC International Virginia, USA.

Alabi, A. J., Ng'ambi, J. W., Mbajiorgu, E. F., Norris, D., \& Mabelebele, M. (2015). Growth and hematological response of indigenous Venda chickens aged 8 to 13 weeks to varying dietary lysine to energy ratios. Journal of Animal Physiology and Animal Nutrition, 99, 436-441. https://doi.org/10.1111/jpn.12277

Alabi, O. O., Atteh, J. O., \& Ogunniyi, P. T. (2014). Effect of Dietary Inclusion of Rice Husk Supplemented with Commercial Enzymes on Performance, Nutrient Retention and Gastrointestinal Tract Characteristics of Arbor Acres Broilers. American Journal of Experimental Agriculture, 4(5), 575-583. https://doi.org/ 10.9734/AJEA/2014/7254

Allain, C. C., Poon, L., Chan, S. G., Richmond, W., \& Fu, P. (1974). Enzymatic determination of total serum cholesterol. Clin Chem, 20, 470.

Benassi, L., Franchi, F., Catina, D., Cioffi, F., Rodella, N., Borgese, L., Pasquali, M., Depero, L. E., ... Bontempi, E. (2015). Rice Husk Ash to Stabilize Heavy Metals Contained in Municipal Solid Waste Incineration Fly Ash: First Results by Applying New Pre-treatment Technology. Materials (Basel, Switzerland), 8(10), 6868-6879. https://doi.org/10.3390/ma8105346

Champe, P. C., Harvery, R. A., \& Ferrier, D. R. (2008). Amino acids: Disposal of Nitrogen. Biochemistry (4th ed., pp. 245-260). Wolters Kluwar (India) Pvt. Ltd., New Delhi.

Cobianchi, J. V., Oliveira, A. S., Campos, J. M. D., Guimaraes, A. V., Valadares, S. D., \& Cobianchi, F. P. (2012). Productive performance and efficiency of utilization of the diet components in dairy cows fed castor meal treated with calcium oxide. Rev Bras Zootecn, 41, 2238-48. https://doi.org/10.1590/S1516-359820120 01000015

Duncan, D. B. (1955). Multiple range and multiple F tests. Biometrics, 11, 1-42. https://doi.org/10.2307/3001478

Elagib, H. A. A., \& Ahmed, A. D. A. (2011). Comparative study on Hematological values of blood of indigenous chickens in Sudan. Asian Journal of Poultry Science, 5(1), 41-45. https://doi.org/10.3923/ajpsaj.2011.41.45

Etim, N. A. N., Akpabio, U., Okpongete, R. O., \& Offiong, E. E. A. (2014). Do Diets Affect Hematological Parameters of Poultry? British Journal of Applied Science \& Technology, 4(13). https://doi.org/10.9734/ BJAST/2014/8900

Fasuyi, A. O., \& Olumuyiwa, T. A. (2012). Evaluating Nutritional Potential of Bio-fermented Rice husk in Broilers Diets. American Journal of Food Technology, 7, 726-735. https://doi.org/10.3923/ajft.2012. 726.735

Flack, C. P., \& Woollen, J. W. (1984). Prevention of interference by dextran with biuret-type assay of serum proteins. Clin Chem, 30, 559-561.

Graham, B. (2010). Introduction to clinical biochemistry: Interpreting blood results. Ventus Publishing.

Haryana. (2018). Mills dump rice husk ash in open, release waste water in empty plots. The Tribune News Service Feb. 5, 2018. Retrieved from https://www.tribuneindia.com/news/haryana/mills-dump-rice-hu sk-ash-in-open-release-waste-water-in-empty-plots/538668.html

Henry T. J. (1974). Clinical Chemistry Principles and Techniques (2nd ed.). Harper and Row Publishers, New York.

Hrabčáková, P., Voslálová, E., Bedáňová, I., Pištjková, V., Chloupek, J., \& Večerek, V. (2014). Haematological and biochemical parameters during the laying period in common pheasant hens housed in enhanced cages. The Scientific World Journal. https://doi.org/10.1155/2014/364602

Jacquie, J. (2015). Common Feed Ingredients in Poultry Diets. Retrieved from http://articles.extension.org/ pages/68432/common-feed-ingredients-in-poultry-diets

Jaime, S. (2005) Diagnostic value of hematology. In G. J. Harrison, \& T. Lightfoot (Eds.), Clinical avian medicine (Volume 11, pp. 588-609). Spix Publishing.

Jiaying, L., John, P. B., Klaus, H., Zhixuan, W., \& Gordon, M. (2016). A comparison of chemical treatment methods for the preparation of rice husk cellulosic fibers. International Journal of Environmental \& 
Agriculture Research, 5(1), 2545-1850.

Koteswara, R. D, Pranav, P. R. T., \& Anusha, M. (2012). Stabilization of expansive soil with rice husk ash, lime gypsum-An experimental study. International Journal of Engineering Science and Technology, 18(6), 131-139.

Lane, R. A. H. T. (2002). Avian Hematology. Retrieved from http://www.exoticpetvet.com/vets/avianhemo tology.htm

Longe, O. G. (1998). Meeting the energy needs of non-ruminants from non-conventional feed sources in Nigeria. Paper presented at Agricultural \& Rural Management Training Institute (ARMTI), Ilorin, Nigeria.

Lumeij, J. T. (1998). Avian Clinical Biochemistry. In J. J. Kaneko, J. W. Harvey, \& M. L. Bruss (Eds.), Clinical Biochemistry of Domestic Animals (pp. 857-884). San Diego, Academic Press.

Madubuike, F. N., \& Ekenyem, B. U. (2006). Hematology and Serum Biochemistry Characteristics of Broiler Chicks Fed Varying Dietary Levels of Ipomoea asarifolia Leaf Meal. International Journal of Poultry Science, 5(1), 09-12. https://doi.org/10.3923/ijps.2006.9.12

Manfred, H. (2013). Biochemistries. Patient Evaluation (Section 2, pp. 224-245). Retrieved from http://avianmedicine.net/content/uploads/2013/03/11.pdf

Milica, Ž. B., Sandra, J., Slobodan, K., \& Miloš, K. (2016). Electrolytes-Sodium, Potassium and Chlorides in Poultry Nutrition. Arhiv Veterinarske Medicine, 9(1), 31- 42.

Nwofoke, C. (2016). Rice Husk Generation and Utilization among Households in Ebonyi State, Nigeria (M.Sc Thesis, University of Nigeria, Nsukka).

Oyawoye, B. M., \& Ogunkunle, H. N. (2004). Biochemical and haematological reference values in normal experimental animals (pp. 212-218). New York: Masson.

Pauzenga, U. (1985). Feeding parent stock. Zootecnia International, 22-25.

Reitman, S., \& Frankel, S. (1957). Colorimetric method for determination of serum transaminases activities. Am. J. Clin. Path., 28, 56-68. https://doi.org/10.1093/ajcp/28.1.56

RIFAN. (2017). Rice production in Nigeria increases to $5.8 \mathrm{~m}$ tonnes in 2017.

Steele, B. W., Koehler, D. F., Azar, M. M., Blaszkowski, T. P., Kuba, K., \& Dempsey, M. E. (1976). Enzymatic determinations of cholesterol in high-density lipoprotein fractions prepared by a precipitation technique. Clin. Chem., 22, 98.

Trinder, P. (1951). A rapid method for the determination of sodium in serum. Analyst, 76, 596-599. https://doi.org/10.1039/an9517600596

Ubwa, S. T., Abah, J., Oshido, B. A., \& Otokpa, E. (2014). Studies on urea treated rice milling waste and its application as animal feed. African Journal of Pure and Applied Chemistry, 8(2), 23-31. https://doi.org/ 10.5897/AJPAC2013.0532

Zhang, Z. F., Cho, J. H., \& Kim, I. H. (2013). Effects of Bacillus subtilis UBT-MO2on growth performance, relative immune organ weight, gas concentration in excreta, and intestinal microbial shedding in broiler chickens. Livestock Science, 155, 343-347. https://doi.org/10.1016/j.livsci.2013.05.021

\section{Copyrights}

Copyright for this article is retained by the author(s), with first publication rights granted to the journal.

This is an open-access article distributed under the terms and conditions of the Creative Commons Attribution license (http://creativecommons.org/licenses/by/4.0/). 